\title{
Effectiveness of electromagnetic monitoring in studying earthquakes
}

\author{
R.H. Piriyev ${ }^{1,2}, 2021$ \\ ${ }^{1}$ Baku State University, Baku, Azerbaijan \\ ${ }^{2}$ Socar's Oil-and-Gas Research and Design Institute, Baku, Azerbaijan
}

Received 8 December 2020

\begin{abstract}
Numerous researches conducted in connection with the study of earthquakes have shown that electromagnetic monitoring studies have led to some important results. From the Loma Prieta earthquake to the Guam earthquake, electromagnetic monitoring studies led to significant results. Since then, there have been numerous reports of possible electromagnetic precursors to earthquakes, some of which have involved frequencies covered by ELF/VLF (10 - $32 \mathrm{kHz})$ monitoring system Fraser—Smith et al. [1990]. Sometime later, they retrieved and started processing their ULF data. They had less reason to expect electromagnetic precursors in this latter data, because previous reports of precursory signals at frequencies below the ELF/VLF range have, with few exceptions, involved frequencies either below or predominantly below their ULF range $(0.01-10 \mathrm{~Hz})$ of operation. They found out that ELF/VLF data do not appear to show precursory activity, whereas ULF data contain a number of anomalous features that may prove to be earthquake precursors. The lack of observation of precursory ELF/VLF noise so close to the epicenters of several moderate to moderately-large earthquakes showed that ELF/VLF noise need not be a strong or obvious feature of every earthquake, as Fraser-Smith et al. [1990] reported in their paper.

At present, numerous studies have been conducted in this area and researches are being improved. From my experience as a young researcher, it became clear that electromagnetic monitoring research is necessary, and that more important and significant results can be achieved if continuous research is conducted in a certain area. Thus, these studies may play a significant role in the detection of earthquake precursors.
\end{abstract}

Key words: electromagnetic, precursor, earthquake, monitoring, MTS.

Introduction. Till now, numerous studies [Corwin, Morrison, 1977; Fraser-Smith et al., 1990; Park et al., 1993; Svetov et al., 1997; Uyeda et al., 2000; Balasco et al., 2004; Caldwell et al., 2004; Moroz et al., 2011; Kalisperi et al., 2013; Booker, 2014; Novruzov, Piriyev 2015; Piriyev, 2017, 2018] have been conducted to detect earthquake precursors and some positive results have been achieved. Among the researches carried out in the direction of detection of earthquake precursors, an example of a study conducted by researchers Y.F. Moroz and T.A. Moroz from the Institute of Volcanology and Seismology of FEB RAS and S.E. Smirnov from the Institute of Cosmophysical Research and Radio Wave Propagation of FEB RAS in 2007-2008 assumed that the anomalous changes they discovered during the study could be related to earthquakes in the regions of the Paratunka and Magadan observatories. So that, in the time series of the magnetic tipper and tensor during 2007-2008 abnormal changes appeared that may be associated with strong earthquakes with $K \geq 6.3$ in the related regions [Moroz et al., 2011]. Before that, electromagnetic monitoring studies were also conducted in Azerbaijan to detect earthquake precursors and from that, important results were obtained. Thus, during 19972002, under the leadership of corresponding member of ANAS, Professor Kerim Kerimov, the Geophysics and Engineering Geology 
Production Association monitored the Earth's naturally changing electromagnetic field for studying the changes in the cycle of electromagnetic fields and the acceleration of the propagation velocity of electromagnetic field variations as earthquake precursors were detected [Piriyev, 2017]. The territory of Azerbaijan is considered a tectonic territory, so it is very important to conduct electromagnetic monitoring there. The map presented in Fig. 1 also clearly describes it, and the map points out that conducting electromagnetic monitoring research in the territory of Azerbaijan is one of the important issues. Because we know that electromagnetic monitoring studies are conducted in geodynamic active areas, and the main goal is aimed at detecting earthquake precursors.

Another example of that kind of researches is the Russian Trofimuk Institute of Petroleum Geology and Geophysics, Candidate of Tech- nical Sciences, senior researcher V.V. Potanov and Doctor of Geological and Mineralogical Sciences, leading researcher E. V. Pospeeva in their investigations saw differences in behavior of apparent resistivity curves and geoelectric models obtained during 2007-2016 of instrumental observations. In their opinion those differences were quite signifficant and were probably related to changes in seismic activity of their studied territory [Potapov, Pospeeva, 2017]. Let's shortly analyze the electromagnetic monitoring studies conducted in Azerbaijan and Russia.

The study by [Kerimov, Agaguliyev, 2001, 2005; Kerimov et al., 2006]. During 19972002, under the leadership of the corresponding member of Azerbaijan National Academy of Sciences, professor Kerim Kerimov, «Geophysics and Engineering Geology» Production Union conducted monitoring of the Earth's natural changing electromagnetic field to stu-

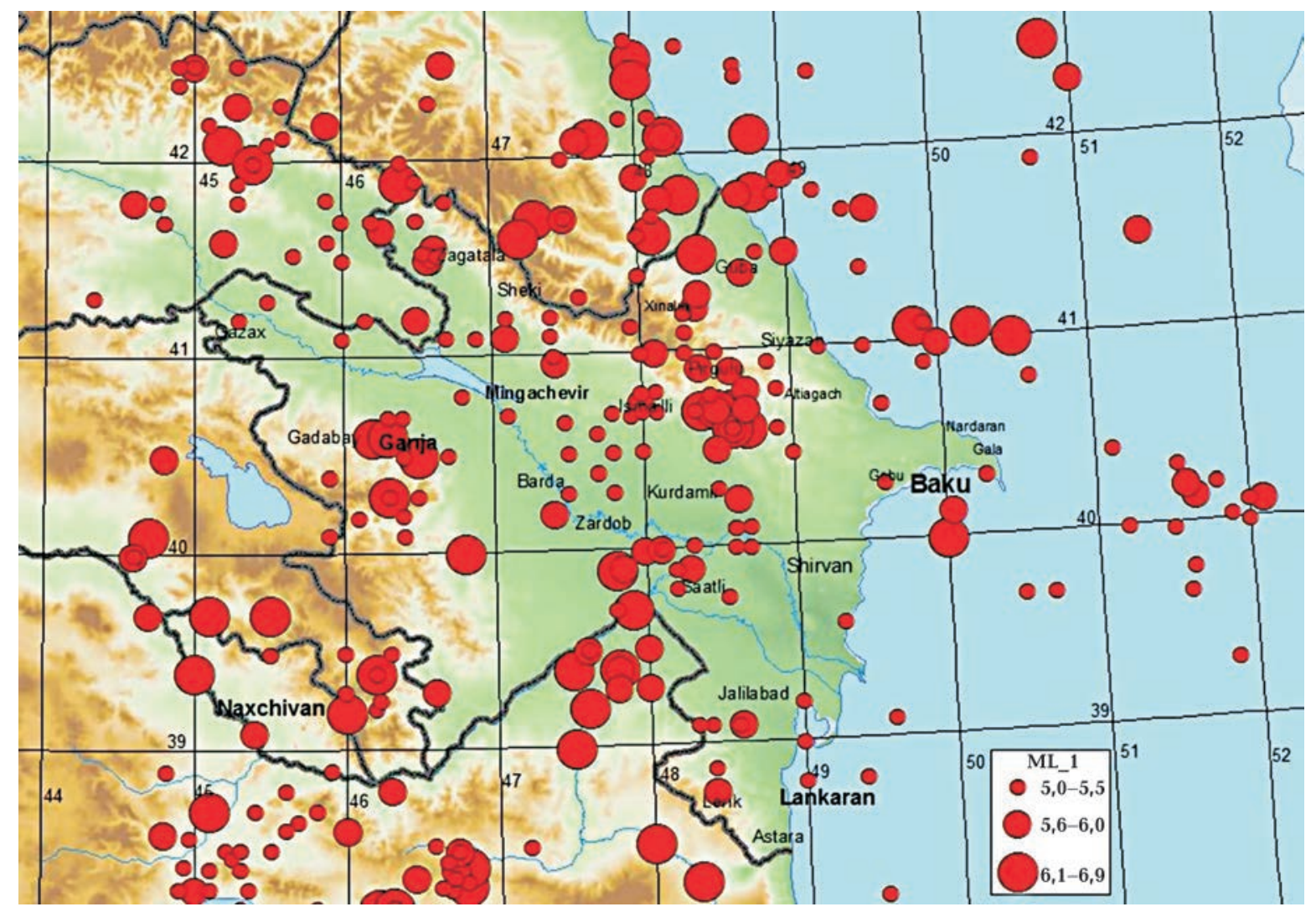

Fig. 1. A Map of epicenter distribution of strong earthquakes ( $M \geq 5.0$ shown in red circles) occurred in Azerbaijan and near territories in the years 427_-2016 as reported by [Yetirmishli et al., 2017, Fig. 1]. 
dy earthquake precursors, and as earthquake precursors, changes in the life cycle of electromagnetic fields and the speed of propagation of electromagnetic field variations were detected. One Azerbaijanian and two Eurasian patents were obtained confirming the existence of these two precursors.

Kerimov and Agaguliyev [2001, 2005] had shown that from the moment characterizing the time of change of the magnetic field cycle, magnetic field intensity vectors were directed towards the future earthquake center. On the other hand, as a result of Kerimov et al. [2006], it was found that the propagation velocity of electromagnetic field (magnetic components) in the direction of the zone in which geodynamic tension occurred and which may subsequently result in an earthquake was rapidly changing, and the coherence of the electromagnetic waves observed before this process was disrupted. In my opinion, the result of a joint study of both processes showed above as an earthquake precursor may lead to the detection of seismic activity and in the future, this could create conditions for the location of earthquake centers related to geodynamic stress zones.

Let's take a deep look at the explanation of the problems mentioned above. It is known that the period of life of the waves, which is connected with the internal magnetic field and is irradiated from the geodynamic stress zones depends on the geodynamics, dimensions, depth, and power of an earthquake center that generates these waves [Piriyev, 2016]. On the other hand, we know that a skin effect was characterized by the period of waves and there is an effective propagation depth of waves corresponding to each period. From that point of view, it becomes clear that geodynamic stress zones will only irradiate waves of the same type and the same period within a certain frame of error.

In 2000-2003, Kerimov et al. [2006] examined the results of electromagnetic monitoring conducted in the Fatmayi polygon, and they came into the conclusion that the violation of the circulation of waves occurred as a result of the superposition of natural electromagnetic waves of cosmic nature, reflected from that depth by waves formed in connection with geodynamic stress zones and anisotrophy.

The study by [Potapov, Pospeeva, 2017]. I briefly describe the way how they carried out electromagnetic monitoring. The recent report of Vladimir V. Potapov and Elena V. Pospeeva [2017] would like to provide relevant news in the search of earthquake precursors by method of MTS. Here I will discuss their significant results starting from the scientific literature before their study.

\section{Possible views on earthquake precursors.}

Goldin et al. [2004] studied the area before and after Chuyskoe earthquake (or Altai earthquake) and came into the conclusion that seismic activity observed in the considered zone in 2002, according to the spatial distribution of the epicenters, differs significantly from the structure of the aftershock processes. Modern ideas about the geodynamic processes occurring in the interior of the Earth during the preparation of an earthquake give reason to believe that these processes are reflected in the data of electromagnetic soundings with artificial and natural sources. Among the methods that allow obtaining information about the deep structure of the Earth, magnetotelluric sounding (MTS) occupies one of the leading places, the main result of the interpretation of which is to reveal the spatial distribution of deep electrical conductivity, reflecting the thermodynamic conditions in the Earth's crust and upper mantle. At present, quite a lot of experience has been accumulated in prognostic regime magnetotelluric observations for studying the geodynamic processes occurring in the Earth's tectonosphere before and during an earthquake [Moroz et al., 2006; Rybin et al., 2009; Matyukov et al., 2010; Batalev et al., 2013]. When studying geodynamic processes using the electromagnetic field of the Earth, there are two approaches: identifying changes in the electrical properties of the geological environment and the structure of variations in the electric and magnetic fields. Electromagnetic monitoring using the MTS method in the Altai Mountains has been carried out for 10 years and based on the implementation of the first approach. The observations were carried out at four points located 

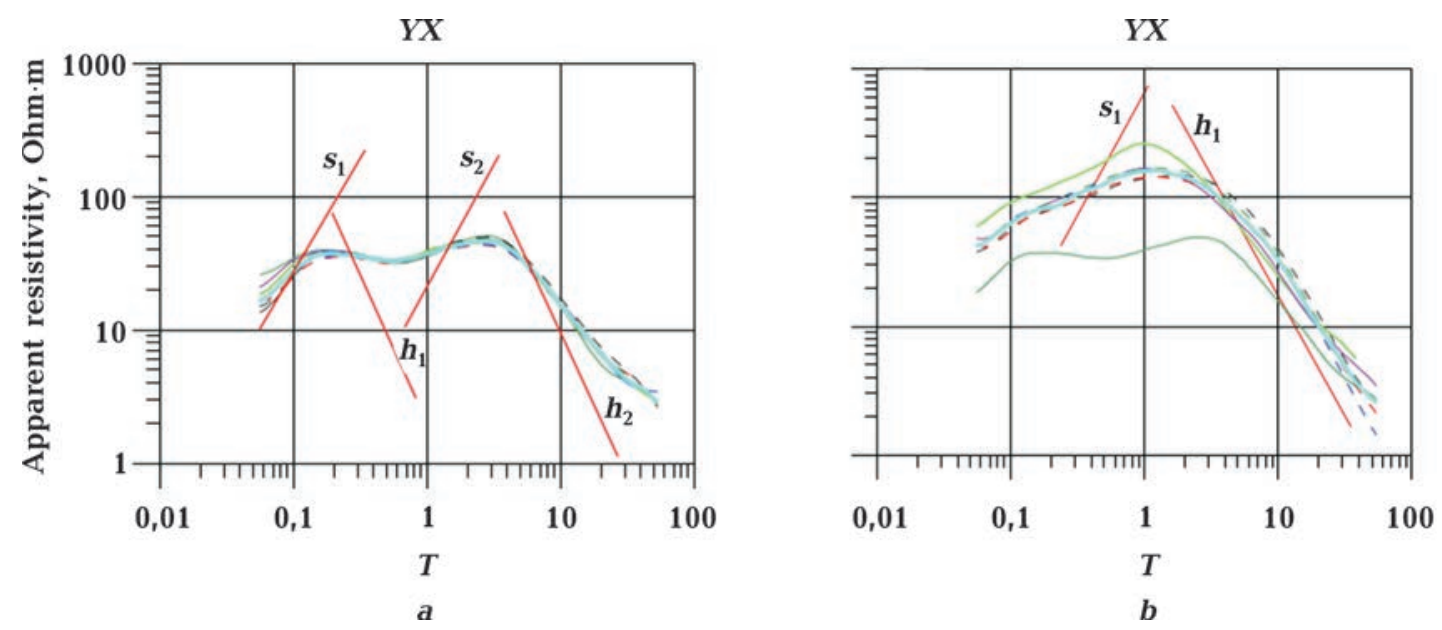

Fig. 2. Apparent resistivity at MTS observation points as reported by [Potapov, Pospeeva, 2017]: $a-1 \mathrm{P} 1 ; b-1 \mathrm{P} 2$. Individual colours are layers which show the differences in resistivity.

in the epicenter zone of the Chuiskoe earthquake. MTS works were carried out by fifthgeneration equipment of the Canadian company «Phoenix Geophysics LTD» in the range of periods $0.003-10000 \mathrm{~s}$. MTU-5 measuring modules were used, which made it possible to register five components (Ex, Ey, $\mathrm{Hx}, \mathrm{Hy}$, $\mathrm{Hz}$ ) of the magnetotelluric field (MT field). A cross-shaped installation with an electric dipole length of $100 \mathrm{~m}$ was used. The components of the MT field were recorded for 22-24 hours. "Phoenix Geophysics LTD» software was used to process field data; $1 \mathrm{D}$ and 2D inversion of experimental data was carried out using the «WinGLink» software package [Pospeeva, 2006].

The surveys were mainly conducted at points 1P1 and 1P2. From the conducted analysis it follows that the lowest deviation (2\%) from the average level is characterized by curved, obtained in the sounding point 1P1 (Fig. 2,a). It increases up to $5 \%$ in the interval S1 due to significant variations in the level of curved resistance (from 12 to $30 \mathrm{Ohm} \cdot \mathrm{m}$ ). The

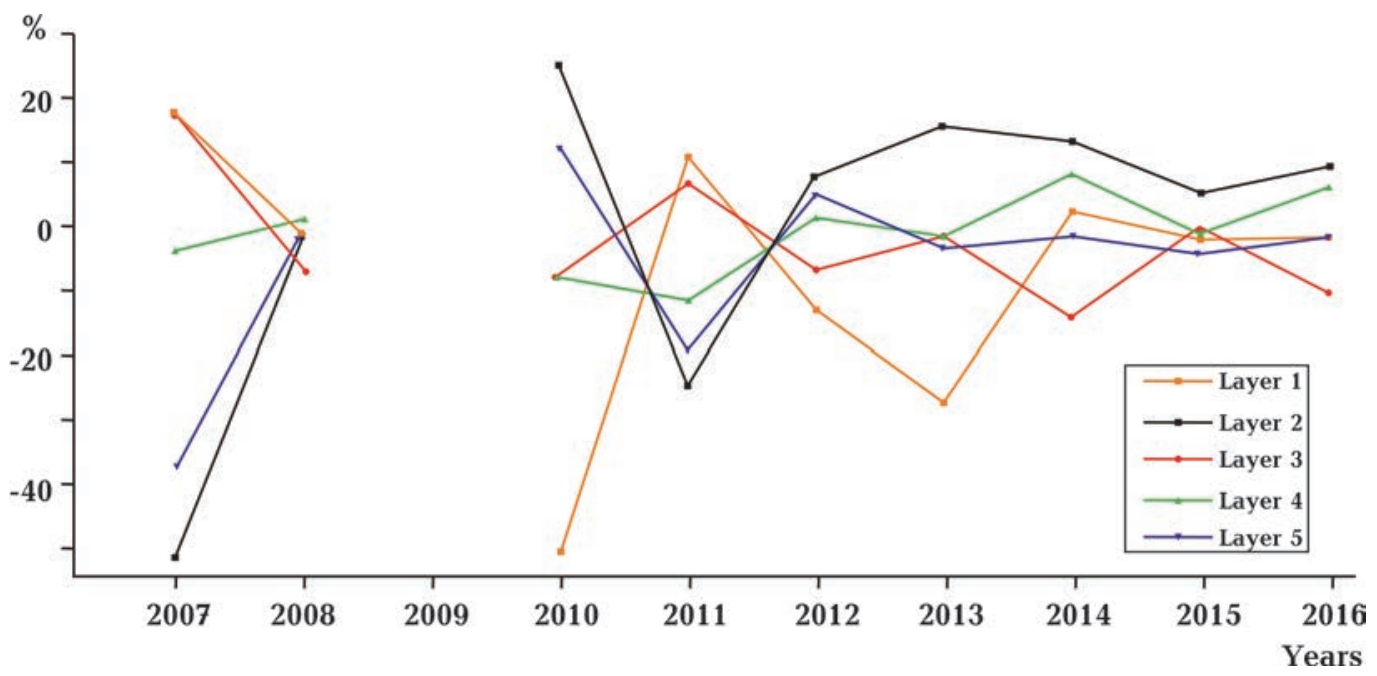

Fig. 3. Relative deviations of apparent resistivity in different layers (layers 1-5) of the geoelectric model in point 1P1 as reported by [Potapov, Pospeeva, 2017]. The layers $1-5$ are coloured in order to show differences in apparent resistivity for the period 2007-2016. 
T a b l e 1 . Precursory signatures before the earthquakes (1996-2015)

\begin{tabular}{|c|c|c|c|c|}
\hline Earthquakes & Researchers [year] & $\begin{array}{l}\text { Approach/Method: } \\
\text { preearthquake changes }\end{array}$ & $\begin{array}{l}\text { Electromagnetic } \\
\text { precursor }\end{array}$ & Results \\
\hline \multirow{5}{*}{$\begin{array}{l}\text { Before Guam } \\
\text { earthquake }\end{array}$} & $\begin{array}{c}\text { Hayakawa et al. } \\
\text { [1996] }\end{array}$ & $\begin{array}{l}\text { Electromagnetic } \\
\text { monitoring: Polarization } \\
\text { ratio time series of } \\
\text { geomagnetic field data }\end{array}$ & $\begin{array}{c}\text { Precursory } \\
\text { signatures of the } \\
\text { earthquake }\end{array}$ & Positive \\
\hline & $\begin{array}{c}\text { Hayakawa et al. } \\
{[1999]} \\
\text { Hobara et al. [2004] } \\
\text { Ida et al. [2005] } \\
\text { Ida, Hayakawa } \\
\text { [2006] } \\
\text { Smirnova et al. } \\
\text { [2001] }\end{array}$ & $\begin{array}{c}\text { Electromagnetic } \\
\text { monitoring: Changes of } \\
\text { ULF magnetic } \\
\text { components before the } \\
\text { earthquake }\end{array}$ & $\begin{array}{c}\text { Precursory sign } \\
\text { of the } \\
\text { earthquake }\end{array}$ & Positive \\
\hline & $\begin{array}{l}\text { Thomas et al. } \\
{[2009 a, b]} \\
\text { Masci } \\
{[2010,2011 \mathrm{a}, \mathrm{b},} \\
\text { 2013a, b] }\end{array}$ & $\begin{array}{l}\text { Electromagnetic } \\
\text { monitoring: Changes } \\
\text { of ULF magnetic } \\
\text { components before the } \\
\text { earthquake }\end{array}$ & $\begin{array}{l}\text { No precursory } \\
\text { sign of the } \\
\text { earthquake }\end{array}$ & Negative \\
\hline & Currie, Water [2014] & $\begin{array}{l}\text { Electromagnetic } \\
\text { monitoring: Polarization } \\
\text { ratio time series of } \\
\text { geomagnetic field data }\end{array}$ & $\begin{array}{c}\text { Precursory } \\
\text { signatures of the } \\
\text { earthquake }\end{array}$ & Positive \\
\hline & $\begin{array}{c}\text { Surkov, Hayakawa } \\
{[2014]}\end{array}$ & $\begin{array}{l}\text { Electromagnetic } \\
\text { monitoring: ULF } \\
\text { disturbances of } \\
\text { geomagnetic field data }\end{array}$ & $\begin{array}{l}\text { Precursory } \\
\text { signature of the } \\
\text { earthquake }\end{array}$ & Positive \\
\hline $\begin{array}{l}\text { A month } \\
\text { before Guam } \\
\text { earthquake }\end{array}$ & $\begin{array}{l}\text { Masci, Thomas } \\
{[2015 a]}\end{array}$ & $\begin{array}{l}\text { Electromagnetic } \\
\text { monitoring: Polarization } \\
\text { ratio time series of } \\
\text { geomagnetic field data }\end{array}$ & $\begin{array}{l}\text { No precursory } \\
\text { signatures of the } \\
\text { earthquake }\end{array}$ & Negative \\
\hline $\begin{array}{l}\text { Between Peru } \\
\text { earthquake } \\
2007 \text { and } 2008\end{array}$ & Takla et al. [2012] & $\begin{array}{c}\text { Electromagnetic } \\
\text { monitoring: long-term } \\
\text { preearthquake changes } \\
\text { in the amplitude of the } \\
\text { geomagnetic field } \\
\text { components, as well as } \\
\text { polarization ratio time } \\
\text { series of geomagnetic } \\
\text { field data }\end{array}$ & $\begin{array}{l}\text { Precursory } \\
\text { signature of the } \\
\text { earthquake }\end{array}$ & Positive \\
\hline $\begin{array}{l}\text { Before Peru } \\
\text { earthquake } \\
2007 \text { and } 2008\end{array}$ & $\begin{array}{l}\text { Masci, Thomas } \\
\text { [2015b] }\end{array}$ & $\begin{array}{c}\text { Electromagnetic } \\
\text { monitoring: long-term } \\
\text { preearthquake changes } \\
\text { in the amplitude of the } \\
\text { geomagnetic field } \\
\text { components, as well as } \\
\text { polarization ratio time } \\
\text { series of geomagnetic } \\
\text { field data }\end{array}$ & $\begin{array}{l}\text { Precursory } \\
\text { signature of the } \\
\text { earthquake }\end{array}$ & Positive \\
\hline
\end{tabular}


T a b l e 2. Anomalous behaviors of electromagnetic signals prior to earthquakes (1995-2016)

\begin{tabular}{|c|c|c|c|c|c|c|}
\hline $\begin{array}{c}\text { Name of } \\
\text { earthquake }\end{array}$ & Date & $\begin{array}{l}\text { Mag- } \\
\text { nitude }\end{array}$ & $\begin{array}{l}\text { Dept } \\
h, \mathbf{k m}\end{array}$ & $\begin{array}{c}\text { Researchers } \\
\text { [year] }\end{array}$ & $\begin{array}{l}\text { Approach/Method: } \\
\text { preearthquake } \\
\text { changes }\end{array}$ & Results \\
\hline $\begin{array}{c}\text { Kobe } \\
\text { (or Great } \\
\text { Hanshin) } \\
\text { earthquake }\end{array}$ & $\begin{array}{l}\text { January } \\
17,1995\end{array}$ & 7.3 & 14.3 & \begin{tabular}{|c|} 
Molchanov \\
et al. \\
[1998] \\
Horie et \\
al. [2006] \\
Hayakawa \\
et al. \\
[2006]
\end{tabular} & $\begin{array}{l}\text { Electromagnetic } \\
\text { monitoring: Research } \\
\text { data obtained before } \\
\text { the earthquake was } \\
\text { used. The differences } \\
\text { in the time curve were } \\
\text { graphically drawn and } \\
\text { tested to see if they } \\
\text { exceeded the } 2 \sigma\end{array}$ & $\begin{array}{l}\text { Some possible } \\
\text { variations } \\
\text { (exceeded the } \\
2 \sigma \text { ) before and } \\
\text { after the } \\
\text { earthquake }\end{array}$ \\
\hline $\begin{array}{l}\text { Leonidio, } \\
\text { Southern } \\
\text { Greece } \\
\text { earthquake }\end{array}$ & $\begin{array}{c}\text { January } \\
6,2008\end{array}$ & 6.2 & 75 & $\begin{array}{l}\text { Ulash } \\
\text { [2011] }\end{array}$ & $\begin{array}{l}\text { The data used in the } \\
\text { study was obtained } \\
\text { from measurements } \\
\text { made over a period } \\
\text { of } 3 \text { months }\end{array}$ & $\begin{array}{c}\text { Variations } \\
\text { of VLF signals } \\
\text { before the } \\
\text { earthquake }\end{array}$ \\
\hline $\begin{array}{l}\text { Erzincan } \\
\text { earthquake }\end{array}$ & $\begin{array}{l}\text { June 30 } \\
2009\end{array}$ & 4.9 & 4 & $\begin{array}{c}\text { Büyüksaraç } \\
\text { et al. } \\
\text { [2015] }\end{array}$ & $\begin{array}{l}\text { It was utilized the } \\
\text { signals received from } \\
5 \text { different stations }\end{array}$ & $\begin{array}{l}\text { Anomalous } \\
\text { behaviors } \\
\text { of VLF signals } \\
\text { before the } \\
\text { earthquake } \\
\text { from only one } \\
\text { station out of } \\
\text { five different } \\
\text { stations }\end{array}$ \\
\hline & $\begin{array}{l}\text { April 25, } \\
2015\end{array}$ & 7.8 & 15 & \multirow{2}{*}{$\begin{array}{l}\text { Phanikumar } \\
\text { et al. } \\
\text { [2018] }\end{array}$} & \multirow{2}{*}{$\begin{array}{l}\text { Continuous signals } \\
\text { of } 19.8 \mathrm{kHz} \text { frequency } \\
\text { were recorded for } \\
24 \text { hours in the study }\end{array}$} & \multirow{2}{*}{$\begin{array}{c}\text { Anomalous } \\
\text { behaviors } \\
\text { of VLF signals } \\
1 \text { day before } \\
\text { each } \\
\text { earthquake }\end{array}$} \\
\hline $\begin{array}{c}\text { Gorkha) } \\
\text { earthquake }\end{array}$ & $\begin{array}{l}\text { May 12, } \\
2015\end{array}$ & 7.3 & 15 & & & \\
\hline $\begin{array}{c}\text { Haity } \\
\text { earthquake }\end{array}$ & $\begin{array}{l}\text { January } \\
10,2010\end{array}$ & 7.0 & 10 & \begin{tabular}{|} 
Hayakawa \\
et al. \\
[2011]
\end{tabular} & $\begin{array}{l}\text { VLF amplitude data } \\
\text { and the trend, } \\
\text { distribution } \\
\text { and changes in night } \\
\text { divergence were } \\
\text { analyzed for the data } \\
\text { that were extensively } \\
\text { studied during the } \\
\text { period from the } \\
\text { beginning of October } \\
2009 \text { to the end } \\
\text { of March } 2010\end{array}$ & $\begin{array}{l}\text { Ionospheric } \\
\text { degradation } \\
12 \text { days before } \\
\text { the earthquake }\end{array}$ \\
\hline $\begin{array}{l}\text { Ishinomaki } \\
\text { earthquake } \\
\text { (Japan) }\end{array}$ & $\begin{array}{l}\text { November } \\
11,2016\end{array}$ & 6.1 & 42 & \multirow{2}{*}{$\begin{array}{l}\text { Asano et } \\
\text { al. [2017] }\end{array}$} & \multirow{2}{*}{$\begin{array}{l}\text { Two different receiver } \\
\text { stations were used } \\
\text { to observe signals. } \\
\text { On November 2-3 } \\
\text { and November 5-8, } \\
\text { 2016, more prominent } \\
\text { anomalies were } \\
\text { identified }\end{array}$} & \multirow{2}{*}{$\begin{array}{l}\text { Anomalous } \\
\text { behaviors } \\
\text { of VLF signals } \\
\text { several days } \\
\text { before the } \\
\text { earthquake }\end{array}$} \\
\hline $\begin{array}{l}\text { Fukushima } \\
\text { earthquake } \\
\text { (Japan) }\end{array}$ & $\begin{array}{l}\text { November } \\
22,2016\end{array}$ & 6.9 & 11 & & & \\
\hline
\end{tabular}


deviation of curves from the average in point 1P2 is $5 \%$ in total, except for curves registered in 2010 and 2012, where it is more than $20 \%$ (Fig. 2,b).

Significant variations in the level of the apparent resistivity curves cause differences in the determined parameters of the geoelectric section (resistivity and power). For example, in point 1P1, significant variations in resistivity values are noted in the interval S1, while in the interval S2, h1 and h2 are within the confidence interval (Fig. 3).

Potapov and Pospeeva [2017] found out that according to the electromagnetic monitoring by method of MTS in the epicentral zone of Chuiskoe earthquake (or Altai earthquake) this method allows you to see the differences in the behavior of the apparent resistance curves and geoelectric models obtained in different years of instrumental observations. These differences are quite significant and are probably associated with a change in the seismic activity of the studied territory. A technique has been developed for analyzing the behavior of apparent resistance curves and parameters of a geoelectric section, based on which further studies will be carried out.

The significant studies of other scientists. The following table (Table 1) summarizes the electromagnetic monitoring studies conducted in different years. Most of the research conducted before the earthquakes in Guam and Peru was aimed at detecting earthquake precursors. As a whole, most cases have achieved

\section{References}

Asano, T., Rozhnoi, A., Solovieva, M., \& Hayakawa, M. (2017). Characteristic Variations of VLF/LF Signals during a High Seismic Activity in Japan in November 2016. Open Journal of Earthquake Research, 6, 204-215. https://doi. org/10.4236/ojer.2017.64013.

Balasco, M., Colangelo, G., Lapenna, V., Loddo, M., Siniscalchi, A., \& Telesca, L. (2004). Measuring apparent resistivity in a seismically active area of southern Italy. Physics Chemistry of the Earth, 29(4-9), 329-337. https://doi.org/10.10 16/j.pce.2003.10.007. positive results with the correct approach. This shows that continuous research can lead to more positive results.

The significant studies to investigate the relationship between VLF signals and earthquakes by different researchers. The following table (Table 2) summarizes the electromagnetic monitoring studies conducted in different years. A lot of researches have been done on the relationship between earthquakes and the variations in very-low-frequency (VLF) signals that occur in the lower layer of the ionosphere before the earthquake.

Conclusions. In the world practice of electromagnetic monitoring research, there are many practical examples of positive results of magnetotelluric research for monitoring geodynamic processes in seismically active regions. The most promising results were obtained in the ULF/VLF range. One of the main problems is that MT signal observed on the surface of the earth is extremely weak, that makes magnetotelluric sounding susceptible to cultural noises. As one of the most common cultural noises during the acquisition of MT data, power line noise has plagued geophysicists for decades [Butler, Russell, 1993; Cohen et al., 2010]. To suppress power line noise, there are trap circuits designed in most of the acquisition instruments, however, the fundamental frequency of the power line noise is changeable with the fluctuate of the load current, hence the MT data are still seriously disturbed by the power line noise.

Batalev, V.Y., Bataleva, E.V., Matyukov, V.E., \& Rybin, A.K. (2013). Deep structure of the western area of Talas-Fergana fault as a result of magnetotelluric sounding. Litosfera, (4), 136145 (in Russian).

Booker, J.R. (2014). The magnetotelluric phase tensor: A critical review. Surveys in Geophysics, 35, 7-40. https://doi.org/10.1007/s10712013-9234-2.

Butler, K.E., \& Russell, R.D. (1993). Subtraction of powerline harmonics from geophysical re- 
cords. Geophysics, 58(6), 898-903. https://doi. org/10.1190/1.1443474.

Büyüksaraç, A., Pinar, A., \& Kaşaroğlu, S. (2015). Precursory anomaly in VLF/LF recordings prior to the Erzincan (Turkey) Earthquake on July 30th, 2009. Bitlis Eren University Journal of Sciences and Technology, 5(1), 18-23. https:// doi.org/10.17678/beujst.63189.

Caldwell, T.G., Bibby, H.M., \& Brown, C. (2004). The magnetotelluric phase tensor. Geophysical Journal International, 158, 457-457. https:// doi.org/10.1111/j.1365-246X.2004.02281.x.

Cohen, M.B., Said, R.K., \& Inan, U.S. (2010). Mitigation of $50-60 \mathrm{~Hz}$ power line interference in geophysical data. Radio Science, 45, RS6002. https://doi.org/10.1029/2010RS004420.

Corwin, R.F., \& Morrison, H.F. (1977). Self-potential variations preceding earthquakes in central California. Geophysical Research Letters, 4(4), 171-174. https://doi.org/10.1029/G L004i004p00171.

Currie, J.L., \& Waters, C.L. (2014). On the use of geomagnetic indices and ULF waves for earthquake precursor signatures. Journal of Geophysical Research Space Physics, 119(2), 992-1003. https://doi.org/10.1002/2013JA019530.

Fraser-Smith, A. C., Bernardi, A., McGill, P.R., Ladd, M.E., Helliwell, R.A., \&Villard, O.G.(1990). Low-frequency magnetic field measurements near the epicenter of the Ms 7.1 Loma Prieta earthquake. Geophysical Research Letters, 17, 1465-1468. https://doi.org/10.1029/GL017i0 $09 \mathrm{p} 01465$.

Goldin, S.V., Seleznev, V.S., Emanov, A.F., Filina, A.G., Emanov, A.A., Novikov, I.S., Visochkiy, E.M., Fateyev, A.V., Kolesnikov, Yu.I., Podkoritova, V.G., Leskova, E.V., \& Yarigina, M.A. (2004). Chuyskoe earthquake and its aftershocks. Doklady RAN, 395(4), 534—536 (in Russian).

Hayakawa, M., Kawate, R., Molchanov, O.A., \& Yumoto, K. (1996). Results of ultra-low-frequency magnetic field measurements during the Guam earthquake of 8 August 1993. Geophysical Research Letters, 23, 241-244. https://doi. org/10.1029/95GL02863.

Hayakawa, M., Ito, T. , \& Smirnova, N. (1999).
Fractal analysis of ULF geomagnetic data associated with the Guam earthquake on August 8, 1993. Geophysical Research Letters, 26, 2797 2800. https://doi.org/10.1029/1999GL005367.

Hayakawa, M., Ohta, K., Maekawa, S., Yamauchi, T., Ida, Y., Gotoh, T., Yonaiguchi, N., Sasaki, H., \& Nakamura, T. (2006). Electromagnetic precursors to the 2004 Mid Niigata Prefecture. Physics Chemistry of the Earth, 31(4-9), 356364. https://doi.org/10.1016/j.pce.2006.02.023.

Hayakawa, M., Raulin, J.P., Kasahara, Y., Bertoni, F.C.P., Hobara, Y., \& Guevara-Day, W. (2011). Ionospheric perturbations in possible association with the 2010 Haiti earthquake, as based on medium-distance subionospheric VLF propagation data. Natural Hazards and Earth System Science, 11(2), 513-518. https://doi.org/ 10.5194/nhess-11-513-2011.

Hobara, Y., Koons, H.C., Roeder, J.L., Yumoto, K., \& Hayakawa, M. (2004). Characteristics of ULF magnetic anomaly before earthquakes. Physics Chemistry of the Earth, 29, 437-444. https: //doi.org/10.1016/j.pce.2003.12.005.

Horie, T., Maekawa, S., Yamauchi, T., \& Hayakawa, M. , (2006). A possible effect of ionospheric perturbations associated with the Sumatra earthquake, as revealed from subionospheric very-low-frequency (VLF) propagation (NWCJapan). International Journal of Remote Sensing, 28(13-14), 3133-3139. https://doi.org/10. $1080 / 01431160601094476$.

Ida, Y., \& Hayakawa, M. (2006). Fractal analysis for the ULF data during the 1993 Guam earthquake to study prefecture criticality. Nonlinear Processes in Geophysics, 13, 409-412. https:// doi.org/10.5194/npg-13-409-2006.

Ida, Y., Hayakawa, M., Adalev, A., \& Gotoh, K. (2005). Multifractal analysis for the ULF Geomagnetic data during the 1993 Guam earthquake. Nonlinear Processes in Geophysics, 12, 157 162. https://doi.org/10.5194/npg-12-157-2005.

Kalisperi, D., Rigakis, I., Makris, J.P., Romano, G. \& Vallianatos, F. (2013). Continuous magnetotelluric observations in Western Crete as a tool for the study of the Hellenic subduction zone. Bulletin of the Geological Society of Greece, Proceedings of the 13th International Congress, Chania, Sept. (Vol. XLVII, pp. 531-539). https://doi.org/10.12681/bgsg.11080. 
Kerimov, K.M., \&Agaguliyev, G.B. (2001). Electromagnetic sounding feasibility to forecast earthquakes. Geophysics news in Azerbaijan, (1), 22-24 (in Russian).

Kerimov, K.M., \& Agaguliyev, G.B. (2005). Stormterm earthquake forecasting potential based on electromagnetic data. Geophysical news in Azerbaijan, (2), 5-8 (in Russian).

Kerimov, K.M., Novruzov, E.S., Veliyev, H.O., \& Suleymanov, G.S. (2006). Earthquake forecasting method. Eurasian patent \#007086, EAPO, EAPV-\#14007087-14. 12.07.2006.

Masci, F. (2011a). Brief communication «On the recent reaffirmation of ULF magnetic earthquakes precursors». Natural Hazards and Earth System Sciences, 11, 2193-2198. https://doi.org /10.5194/nhess-11-2193-2011.

Masci, F. (2013a). Further comments on the ionospheric precursor of the 1999 Hector Mine earthquake, Natural Hazards and Earth System Sciences, 13, 193-196. https://doi.org/10.5194/nhess13-193-2013.

Masci, F. (2010). On claimed ULF seismogenic fractal signatures in the geomagnetic field. $J_{O}$ urnal of Geophysical Research: Space Physics, 115, A10236. https://doi.org/10.1029/ 2010JA 015311.

Masci, F. (2013b). On the multi-fractal characteristics of the ULF geomagnetic field before the 1993 Guam earthquake. Natural Hazards and Earth System Sciences, 13, 187-191. https://doi. org/10.5194/nhess-13-187-2013.

Masci, F. (2011b). On the seismogenic increase of the ratio of the ULF geomagnetic field components, Physics of the Earth and Planetary Interiors, 187, 19-32. https://doi.org/10.1016/j. pepi.2011.05.001.

Masci, F., \& Thomas, J.N. (2015a). Comment on «Ultra low frequency (ULF) electromagnetic anomalies associated with large earthquakes in Java Island, Indonesia by using wavelet transform and detrended fluctuation analysis», by Febriani et al. (2014), under review. Natural Hazards and Earth System Sciences Discussions, 3(9), 5665-5675. https://doi.org/ 10.5194/nhessd-3-5665-2015.

Masci, F., \& Thomas, J.N. (2015b). On the re- liability of the Spatial Scintillation Index to identify ionospheric precursors of earthquakes. Radio Science, 50, 745-753. https://doi.org/10. 1002 /2015RS005734.

Matyukov V.E., Spichak V.V., Rybin A.K. et al. (2010) Application of a neural network approach to analyze the correlation of magnetotelluric parameters with the seismic activity of the Northern Tien Shan region. Forecast of earthquakes, assessment of seismic hazard and seismic risk of Central Asia. 7th Kazakh-Chinese International. simp.: theses. Almaty, $47 \mathrm{p}$.

Molchanov, O.A., Hayakawa, M., Oudoh, T., \& Kawai, E. (1998). Precursory effects in the subionospheric VLF signals for the Kobe earthquake. Physics of the Earth and Planetary Interiors, 105(3-4), 239-248. https://doi.org/10.1016/ S0031-9201(97)00095-2.

Moroz, Y.F., Moroz, T.A., \& Smirnov, S.E. (2011). Results of monitoring the variations of the geomagnetic field at the Magadan and Paratunka observatories. Fizika Zemli, (8), 49-61 (in Russian).

Moroz, Y.F., Smirnov, S.E., \& Moroz, T.A. (2006). Results of monitoring variations of the geomagnetic field in Kamchatka. Fizika Zemli, (3), 49-56 (in Russian).

Novruzov E.S., Piriyev R.H. (2015). Efficiency of magnetotelluric monitoring in the study of geodynamic processes. Gorno-geologicheskiy Zhurnal, (3-4), 36-39 (in Russian).

Park, S.K., Johnston, M.J.S., Madden, T.R. Morgan, F.D., \& Morrison, H.F. (1993). Electromagnetic precursors to earthquakes in the ULF band: A review of observations and mechanisms. Reviews of Geophysics, 31(2), 117 132. https://doi.org/10.1029/93RG00820.

Phanikumar, D.V., Maurya, A.K., Kumar, K.N. Venkatesham, K., Singh, R., Sharma, S., \& Naja, M. (2018). Anomalous variations of VLF subionospheric signal and Mesospheric Ozone prior to 2015 Gorkha Nepal Earthquake. Scientific Reports, 8, 9381. https://doi.org/10.1038/s4 1598-018-27659-9.

Pospeeva, E.V. (2006). Methodological manual on the application of magnetotelluric sounding in medium-scale diamond prospecting works. Mirny, 75 p. (in Russian). 
Potapov, V.V., \& Pospeeva, E.V. (2017). Electromagnetic Monitoring by Method of MTS in the Epicentral Zone of Chuiskoe Earthquake. Interexpo GEO-Siberia-2017. XIII International Scientific Congress (Novosibirsk, April 17-21, 2017): International Scientific Conference «Subsoil Use. Mining. Directions and technologies of prospecting, exploration and development of mineral deposits. Economy. Geoecology» (Vol. 3, pp. 167-171) (in Russian).

Piriyev, R.H. (2018). Analysis of Electromagnetic Monitoring in Geodynamic Active Areas. International Journal of Earth Science and Geophysics, (4), 1-9.https://doi.org/10.35840/26315033/1821.0.

Piriyev, R.H. (2017). The issue of identification of earthquake precursors on magnitotelluric research materials. Problemy sovremennoy nauki i obrazovaniya, (21). (in Russian).

Piriyev, R.H. (2016). On the efficiency of electromagnetic monitoring. Materials of the Republican Scientific Conference "Actual problems of Geology" dedicated to the 93rd Anniversary of the National Leader of the Azerbaijani people Heydar Aliyev, Baku-2016, p. 235.

Rybin, A., Batalev, V., Bataleva, E., \& Matukov, V. (2009). Magnetotelluric monitoring experiment at the Northern Tien Shan seismogenic zone. 11th Scientific Assembly IAGA. Sopron (Hungary), August 23-30, 2009. Abstracts-CD-106TUE-P1700-0600.

Smirnova, N., Hayakawa, M., Gotoh, K., \& Volobuev, D. (2001). Scaling characteristics of the ULF geomagnetic fields at the Guam seismoactive area and their dynamics in relation to the earthquake, Natural Hazards and Earth System Sciences , 1, 119-126. https://doi.org/ 10.5194/nhess-1-119-2001.

Surkov, V., \& Hayakawa, M. (2014). Ultra and Ex- temely Low Frequency Electromagnetic Fields. Tokyo: Springer, 486 p. https://doi.org/10.1007/ 978-4-431-54367-1.

Svetov, B.S., Karinskij, S.D., Kuksa, Y.I., \& Odintsov, V.I. (1997). Magnetotelluric monitoring of geodynamical processes. Anali di Geofisica, 40 (2), 435-443. https://doi.org/10.4401/ag-3920.

Takla, E.M., Yumoto, K., Ishitsuka, J., Rosales, D. Dutra, S., Uozumi, T., \&Abe, T. (2012). Geomagnetic variations possibly associated with the Pisco earthquake on 15 August 2007, Peru. Tectonophysics, 524-525, 29-36. https://doi.org/ 10.1016/j.tecto.2011.12.008.

Thomas, J.N., Love, J.J., \& Johnston, M.J.S. (2009a). On the reported magnetic precursor of the 1989 Loma Prieta earthquakes. Physics of the Earth and Planetary Interiors, 173(3-4), 207-215. https://doi.org/10.1016/j.pepi.2008. 11.014 .

Thomas, J.N., Love, J.J., Johnston, M.J.S., \& Yumoto, K. (2009b). On the reported magnetic precursor of the 1993 Guam earthquake. Geophysical Research Letters, 36, L16301. https:// doi.org/10.1029/2009GL039020.

Ulash, M. (2011). Development of an algorithm by using VLF signals for predicting earthquakes. University of Firat, PhD thesis, Elazigh.

Uyeda, S., Nagao, T., Orihara, Y., Yamaguchi, T. \& Takahashi, I. (2000). Geoelectric potential changes: Possible precursors to earthquakes in Japan. PNAS, 97(9), 4561—4566. https://doi. org/10.1073/pnas.97.9.4561.

Yetirmishli, G.J., Mammadli, T.Y., Muradov, R.B. \& Jafarov, T.I. (2017). About the seismic risk of Sabayil district of Baku. Seismoprogn. Seismoprognosis Observations in the Territory of Azerbaijan, 14(1), 12-21. 


\title{
Ефективність електромагнітного моніторингу при вивченні землетрусів
}

\author{
P.X. ПipieB ${ }^{1,2}, 2021$ \\ ${ }^{1}$ Бакінський державний університет, Баку, Азербайджан \\ ${ }^{2}$ Науково-дослідний проектний інститут «Нафтогаз» (SOCAR), \\ Баку, Азербайджан
}

\begin{abstract}
Завдяки численним дослідженням методами електромагнітного моніторингу землетрусів, в тому числі близько Лома-Прієта і на Гуамі, отримані деякі важливі результати. 3 того часу з'явилося багато нової інформації про можливі електромагнітні провісники землетрусів, причому деякі спостереження зафіксовані на частотах ЭНЧ/ОНЧ (10-32 кГц) системою моніторингу Фрейзера та ін. [1990]. Пізніше була проведена обробка їх УНЧ-даних. Було мало підстав очікувати електромагнітних проявів провісників в цих пізніших даних, тому що попередні повідомлення про сигнали провісників з частотами нижче ЭНЧ/ОНЧ діапазону, за небагатьох винятків, включили частоти або нижче, або переважно нижче їх УНЧ-діапазону $(0,01-10$ Гц ). Було встановлено, що ЭНЧ/ОНЧ дані не показують провісників, в той час як УНЧдані містять деяку кількість аномальних особливостей, які можуть виявитися провісниками землетрусу. Спостереження ЭНЧ/ОНЧ шуму передвісника близького до епіцентру віддекількох середніх до великих землетрусів показало, що ЭНЧ/ОНЧ шум може не бути сильною або очевидної особливістю кожного землетрусу [ФрейзерСміт і ін., 1990]. В даний час проводяться численні подібні дослідження, а їх якість поліпшується. 3 мого досвіду, як молодого дослідника, стає ясно, що проведення електромагнітного моніторингу необхідно, і що більш важливі і значні результати можуть бути отримані, якщо такі дослідження будуть безперервними. Таким чином, вони можуть зіграти важливу роль у виявленні провісників землетрусів.
\end{abstract}

Ключові слова: електромагнітний провісник, землетрус, моніторинг, МТЗ.

\section{Эффективность электромагнитного мониторинга при изучении землетрясений}

\author{
P.X. Пириев ${ }^{1,2}, 2021$ \\ ${ }^{1}$ Бакинский государственный университет, Баку, Азербайджан \\ ${ }^{2}$ Научно-исследовательский проектный институт «Нефртегаз» (SOCAR), \\ Баку, Азербайджан
}

Благодаря многочисленным исследованиям методами электромагнитного мониторинга землетрясений, в том числе около Лома-Приета и на Гуаме, получены некоторые важные результаты. С того времени появилось много новой информации о возможных электромагнитных предвестниках землетрясений, причем некоторые наблюдения зафиксированы на частотах ЭНЧ/ОНЧ (10-32 кГц) системой мониторинга Фрейзера и др. [1990]. Позже была проведена обработка их УНЧ-данных. Было мало оснований ожидать электромагнитных проявлений предвестников в этих более поздних данных, потому что предыдущие сообщения о сигналах предвестников с 
частотами ниже ЭНЧ/ОНЧ диапазона, при немногих исключениях, включили частоты либо ниже, либо преимущественно ниже их УНЧ-диапазона (0,01-10 Гц). Было установлено, что ЭНЧ/ОНЧ данные не показывают предвестников, в то время как УНЧ-данные содержат некоторое количество аномальных особенностей, которые могут оказываться предвестниками землетрясения. Наблюдения ЭНЧ/ОНЧ шума предвестника близкого к эпицентрам от нескольких средних до крупных землетрясений показало, что ЭНЧ/ОНЧ шум может не быть сильной или очевидной особенностью каждого землетрясения [Фрейзер-Смит и др., 1990]. В настоящее время проводятся многочисленные подобные исследования, а их качество улучшается. Из моего опыта, как молодого исследователя, становится ясно, что проведение электромагнитного мониторинга необходимо, и что более важные и значительные результаты могут быть получены, если такие исследования будут непрерывными. Таким образом, они могут сыграть важную роль в обнаружении предвестников землетрясений.

Ключевые слова: электромагнитный предвестник, землетрясение, мониторинг, MT3. 